\section{The DNA damage signaling pathway is a critical mediator of oncogene-induced senescence}

\author{
Frédérick A. Mallette, \\ Marie-France Gaumont-Leclerc, \\ and Gerardo Ferbeyre ${ }^{1}$
}

Département de Biochimie, Université de Montréal, Montréal, Québec H3C 3J7, Canada

Here we report that RNA interference against ATM inhibited p53 accumulation in cells expressing oncogenic STAT5 and cooperated with $R$ b inactivation to suppress STAT5A-induced senescence. Knocking down ATM was also effective to bypass E2F1-induced senescence and in combination with $\mathrm{Rb}$ inactivation, inhibited RasV12-induced senescence. Cells that senesced in response to caSTAT5A or RasV12 accumulated DNA damage foci and activated ATM, ATR, Chk1, and Chk2, indicating that aberrant oncogene activation induces a DNA damage signaling response. Intriguingly, bypassing oncogene-induced senescence by inactivation of $\mathrm{p} 53$ and $\mathrm{Rb}$ did not eliminate the accumulation of oncogene-induced DNA damage foci (ODDI), suggesting a mechanism that may limit transformation in immortalized cells.

Supplemental material is available at http://www.genesdev.org.

Received August 29, 2006; revised version accepted November 15, 2006.

Normal cells possess natural defenses against transformation into cancer cells. Oncogenes, such as myc or E1A, trigger a cell death program while oncogenes such as ras, raf, or mek induce a permanent growth-arrest program indistinguishable from the senescence response previously characterized during serial passage of primary fibroblasts (Lowe et al. 2004). The tumor suppressor pathways controlled by $\mathrm{p} 53$ and $\mathrm{Rb}$ are necessary for the senescence program (Serrano et al. 1997), and other tumor suppressors have also been linked to senescence (Lowe et al. 2004). Although Rb and p53 represent two important control points in the senescence network, the proteins connecting oncogenic activity to these tumor suppressors are also critical for an efficient anti-tumor response. Several candidate proteins have been proposed to connect oncogenes to p53. The first described was ARF, which is activated by multiple oncogenic stimuli (de Stanchina et al. 1998; Zindy et al. 1998, 2003) and is required for induction of p53 and senescence in response to oncogenic ras in mouse primary fibroblasts (Palmero et al. 1998; Ferbeyre et al. 2002) or keratinocytes (Lin and

[Keywords: STAT5; RasV12; E2F1; ATM; DNA damage; p53; senescence] ${ }^{1}$ Corresponding author.

E-MAIL g.ferbeyre@umontreal.ca; FAX (514) 343-2210.

Article is online at http://www.genesdev.org/cgi/doi/10.1101/gad.1487307.
Lowe 2001). On the other hand, oncogenic ras does not induce p53 via ARF in human fibroblasts and, as a consequence, ARF is not required for ras-induced senescence in these cells (Wei et al. 2001). ARF was also dispensable for $\mathrm{p} 53$ activation and apoptosis after $\mathrm{Rb}$ inactivation and E2F induction in mice (Tolbert et al. 2002). Other candidates connecting oncogenic ras to p53 are the p38 mitogen-activated protein kinase (MAPK) pathway (Deng et al. 2004), PML protein (Ferbeyre et al. 2000; Pearson et al. 2000), PEA-15 (Gaumont-Leclerc et al. 2004), and seladin (Wu et al. 2004). In summary, multiple signaling pathways seem to connect RasV12 to p53, and no unique sensor of oncogenic activity has yet emerged from these studies.

To investigate the nature of the signals that activate the p53 pathway during senescence, we thought that it would be valuable to compare two oncogenes that activate different signaling pathways. We anticipated that each oncogene might trigger specific pathways, but also that a general cellular stress could signal an oncogenic threat in the cells. Therefore, we generated a novel model of oncogene-induced senescence using a constitutively active allele of STAT5 (ca-STAT5). STAT5A together with STAT5B are transcription factors that mediate cytokine and hormone signals. Their constitutive activation has been observed in several human cancers, and they are oncogenic in cell culture models and transgenic animals (Bowman et al. 2000). In this study, we report that knocking down ATM expression with a short hairpin RNA (shRNA) blocked p53 induction in response to aberrant STAT5A activation and bypassed the senescence response to this oncogene when the $\mathrm{Rb}$ pathway was also inactivated. Knocking down ATM also inhibited E2F1-induced senescence and, in combination with $\mathrm{Rb}$ inactivation, suppressed RasV12-induced senescence. In agreement, normal cells expressing ca-STAT5 or RasV12 accumulated DNA damage foci and exhibited a constitutive activation of the DNA damage signaling pathway. Bypassing senescence by inactivating the p53 and the $\mathrm{Rb}$ tumor suppressor pathways did not eliminate the DNA damage foci, explaining why they persist in premalignant lesions and may constitute an additional barrier to full oncogenic transformation.

\section{Results and Discussion}

Induction of p53 and senescence by ca-STAT5A requires $A T M$

To investigate the pathways linking oncogenes to p53 and senescence, we first infected normal human diploid fibroblasts IMR90 or BJ (data not shown) with retroviruses expressing a constitutive allele of STAT5A (caSTAT5A), also known as STAT5A1*6 (Onishi et al. 1998 ) or an empty vector. Ca-STAT5A induced a cell cycle arrest with the characteristics of cellular senescence (Fig. 1A) including low BrdU incorporation and the nuclear accumulation of the p53 tumor suppressor protein (Fig. 1B). In previous studies, we found that the ATM kinase and the DNA damage signaling pathway was required for senescence in response to $\beta$-interferon (Moiseeva et al. 2006). To investigate if a similar pathway was active in cells expressing ca-STAT5A we knocked down ATM expression using an already vali- 
Mallette et al.

A

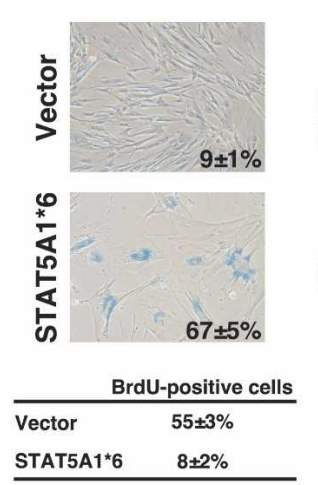

B

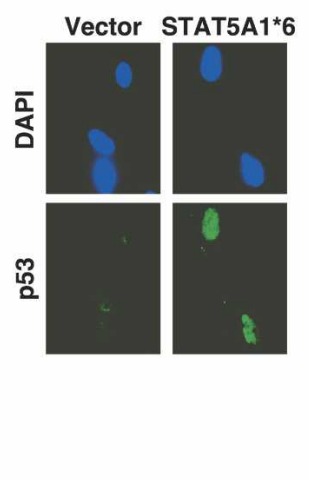

C

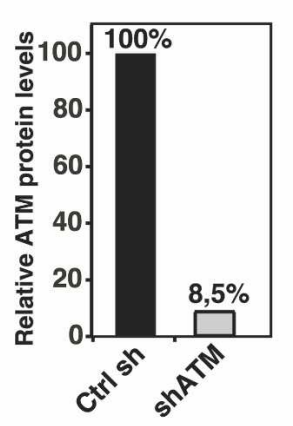

E
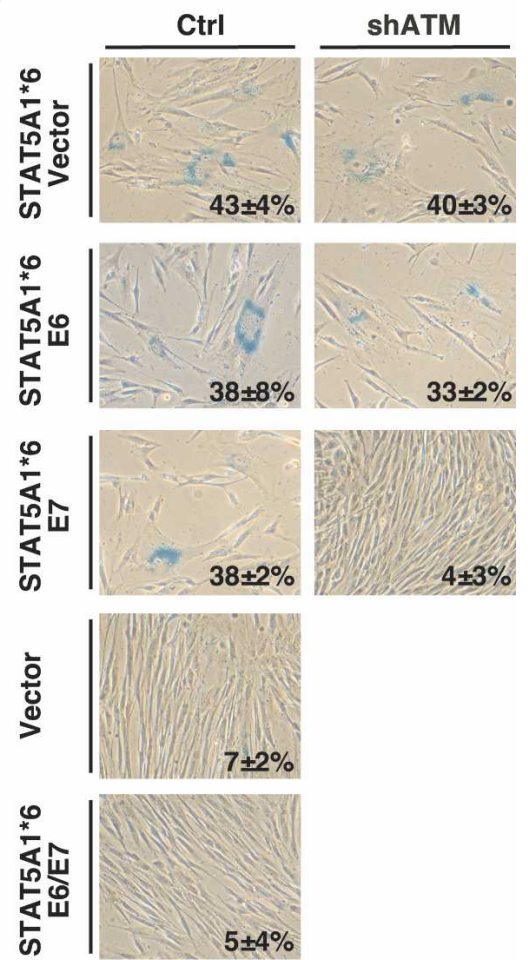

$\mathbf{F}$

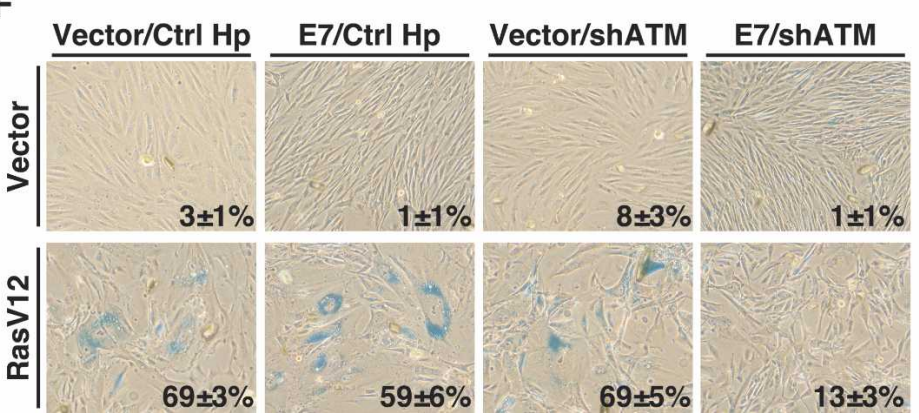

Figure 1. ATM is critical for oncogene-induced senescence. (A) SA- $\beta$-gal staining of human diploid fibroblasts IMR90 infected with control vector or ca-STAT5A. The percent of SA- $\beta$-gal-positive cells is indicated at the bottom of each panel. The percent of cells that incorporate BrdU is shown below the panels. (B) Indirect immunofluorescence showing p53 induction by ca-STAT5A in cells fixed $8 \mathrm{~d}$ after infection. $(C)$ Quantitation of ATM protein levels in IMR90 infected with a control hairpin or the anti-ATM hairpin vector. $(D)$ Indirect p53 immunofluorescence in IMR90 cells expressing the indicated vectors. The staining intensity is translated into a color code using Metamorph software. (E) Rescue of ca-STAT5A-induced senescence by shRNA against ATM measured by SA- $\beta$-gal staining. IMR90 cells bearing the empty vector LXSN or its derivatives expressing E6 or E7 were infected with an empty vector or its derivative expressing an shRNA against ATM together with STAT5A1*6. The percent and standard deviation of SA- $\beta$-gal-positive cells are indicated at the bottom right of each panel. Data represent three independent experiments done with cells collected $6 \mathrm{~d}$ post-selection. $(F)$ Rescue of RasV12-induced senescence by shRNA against ATM measured by SA- $\beta$-gal staining. Fibroblasts bearing the empty vector LXSN or its derivative expressing E7 were infected with an empty vector or its derivative expressing an shRNA against ATM together with RasV12. The percent and standard deviation of SA- $\beta$-gal-positive cells are indicated at the bottom right of each panel. Data represent three independent measurements done with cells fixed $14 \mathrm{~d}$ post-selection.

dated shRNA (shATM) (Fig. 1C; Mukhopadhyay et al. 2005; Moiseeva et al. 2006). Cells expressing shATM accumulated much less p53 than cells expressing a control hairpin (Fig. 1D), but did not bypass the senescent response to ca-STAT5A in normal human fibroblasts (Fig. 1E). STAT5A-induced senescence was not bypassed in cells expressing the human papillomavirus oncoproteins E6 or E7, which inactivate the p53 and the Rb pathway, respectively. However, coexpressing both E6 and E7 did circumvent ca-STAT5A-induced senescence (Fig. 1E). In agreement with the ability of shATM to inhibit p53 accumulation in response to ca-STAT5A, combining
shATM with E7 but not with E6 also blocked caSTAT5A-induced senescence (Fig. 1E). In this way, shATM acted genetically as a p53 suppressor. We concluded that either the p53 or the Rb pathway is sufficient for the senescence response to STAT5A, and that the p53 pathway was activated via the DNA damage-responsive kinase ATM.

To extend these results to other oncogenes, we studied the effect of shATM on the senescence response to E2F1 and RasV12. E2F1-induced senescence can be rescued upon inactivation of p53 alone (Dimri et al. 2000). In agreement, shATM rescued E2F1-induced senescence as 
efficiently as an shRNA against p53 (Supplementary Fig. 1). In contrast, to STAT5A-induced senescence, RasV12induced senescence is more complex, and cannot be entirely rescued with E6 and E7 (Mallette et al. 2004). Coexpression of RasV12 with E7 and shATM did not prevent the senescence of most cells in the population, but after $12 \mathrm{~d}$ in cultures we visualized colonies of SA- $\beta$-Galnegative cells that could further propagated with few signs of senescence (Fig. 1E). Taken together, these results suggest that the DNA damage signaling pathway is critical for the senescence response to oncogenes.

\section{STAT5A and RasV12 induce a constitutive activation of the DNA damage signaling pathway}

ATM is activated by double-stranded breaks and other forms of damage to DNA (Bakkenist and Kastan 2003). These lesions can be readily visualized using antibodies against $\gamma \mathrm{H} 2 \mathrm{AX}$, which is a phosphorylated version of the histone H2AX at Ser 139 (d'Adda di Fagagna et al. 2003; Bartkova et al. 2005; Gorgoulis et al. 2005). Staining with these antibodies revealed the presence of DNA damage foci in cells that were induced to senesce by oncogenic STAT5A, oncogenic ras, or hydrogen peroxide (Fig. 2A,B).

To further characterize the DNA damage foci in cells expressing ca-STAT5A or RasV12, we performed confocal immunofluorescence to reveal other components of the DNA damage foci. First, these foci were labeled with

A

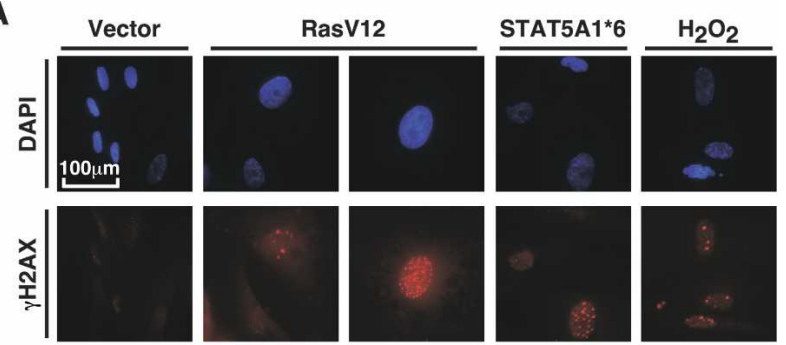

B

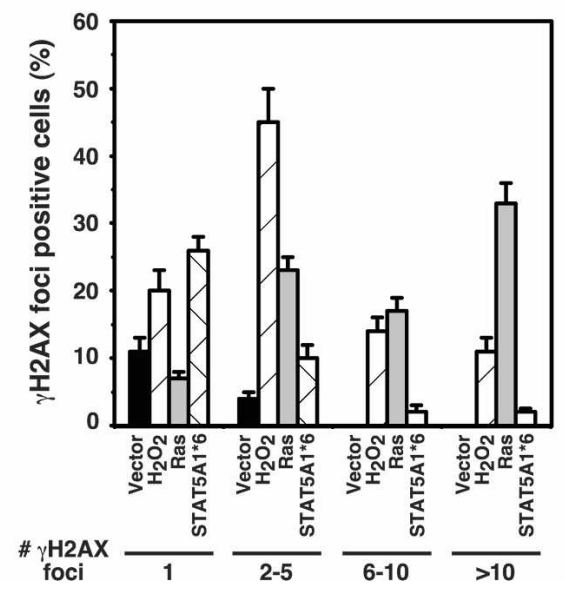

Figure 2. DNA damage foci in oncogene-induced senescence. $(A)$ Indirect immunofluorescence for $\gamma \mathrm{H} 2 \mathrm{AX}$ foci in cells expressing control vector, RasV12, or STAT5A1 *6. As a positive control, cells were treated with hydrogen peroxide. $(B)$ Quantitation of the number of $\gamma \mathrm{H} 2 \mathrm{AX}$ foci. Histogram indicates the number of cells containing one, two to five, six to 10 , and $>10$ foci. The data represent the average and standard deviation of three independent counts of 100 cells each. an antibody against 53BP1 (Fig. 3A; Supplementary Figs. 2,31 , a component of the DNA damage response required for p53 activation (Wang et al. 2002). Next, these foci were stained by an antibody that recognizes ATM phosphorylated at Ser 1981, which indicates activation of this kinase (Fig. 3A; Supplementary Fig. 3; Bakkenist and Kastan 2003). In agreement, we found that antibodies against the phospho-epitope $\mathrm{pS} / \mathrm{TQ}$, which is the consensus phosphorylation site of ATM and ATR, also labeled foci (Fig. 3B). Quantitation of the data using indirect immunofluorescence, confirmed again that cells expressing oncogenic STAT5A have multiple DNA damage foci when compared with normal cells expressing a vector control (Fig. 3C). Foci containing $\gamma \mathrm{H} 2 \mathrm{AX}$ or pS/TQ epitopes were more numerous than foci labeled by phospho$\mathrm{ATM}^{\mathrm{S} 1981}$ or the ATM target phospho-53BP1, suggesting that other PIKKs (PI3 kinase-like kinases) are active in senescent cells. In accord, we detected numerous ATR foci in cells expressing either RasV12 or ca-STAT5A (Supplementary Fig. 4). However, the pattern of ATR staining was different from the pattern induced by replication arrest in cells treated with hydroxyurea (Supplementary Fig. 4), suggesting that the oncogenic pathway to ATR activation does not involve a classic S-phase arrest. This is consistent with the fact that senescence induced by RasV12 (Serrano et al. 1997) or ca-STAT5A (data not shown) involves an arrest in G1. In addition, both ca-STAT5A and RasV12 induced Chk1 phosphorylation at Ser 317, a site known to be phosphorylated by ATR (Zhao and Piwnica-Worms 2001) or ATM (Gatei et al. 2003). Intriguingly, ca-STAT5A induced Chk2 phosphorylation at Thr 68 (Fig. 3D), while RasV12 induced phosphorylation of Chk2 at Ser 19. Both sites are part of a cluster of S/TQ phosphorylation sites that are recognized by PIKKs such as ATM and ATR (Matsuoka et al. 2000). It is not presently clear why these two oncogenes induce a different phosphorylation pattern in Chk2, but it is known that all S/TQ sites in the $\mathrm{N}$ terminus of Chk2 are individually sufficient to activate the protein (Xu et al. 2002). As expected, shATM blocked the phosphorylation of Chk2 at Thr 68 in cells expressing caSTAT5A (Fig. 3E). Together, these results suggest that DNA damage foci are constitutively signaling through protein phosphorylation in cells expressing ca-STAT5A or RasV12.

DNA damage foci that accumulate in replicative senescence are organized around short telomeres, which may look like double-stranded breaks (d'Adda di Fagagna et al. 2003). However, as shown in Supplementary Figure 5, oncogene-induced DNA damage foci (ODDI) did not colocalize with telomeres, as identified with an antibody against TRF2. In agreement, expression of telomerase alone or in combination with E6 or E7 did not rescue senescence in response to ca-STAT5A (data not shown) or RasV12 (Wei et al. 1999). These results suggest that oncogenes do not activate the DNA damage signaling pathway by promoting telomere shortening or uncapping. The activation of the DNA damage signaling pathway we observe in oncogene-induced senescence can be secondary to multiple kinds of damage to DNA and chromatin induced by aberrant oncogenic activity (Rouse and Jackson 2002). This response can be activated by DNA damaging agents such as reactive oxygen species (Lee et al. 1999; Vafa et al. 2002; Wu et al. 2004; Moiseeva et al. 2006 ) but also by stalled replications forks (Osborn et al. 2002), altered nucleus-cytoplasmic ratio (Shimuta et al. 
Mallette et al.

A

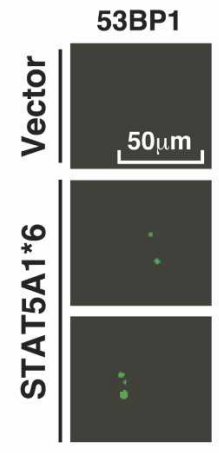

B
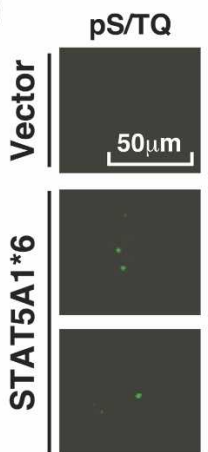
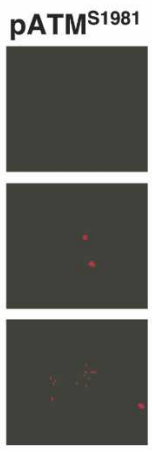

$\gamma \mathrm{H} 2 \mathrm{AX}$
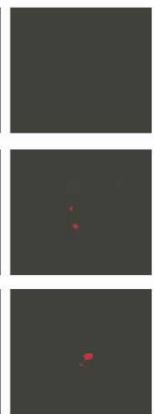
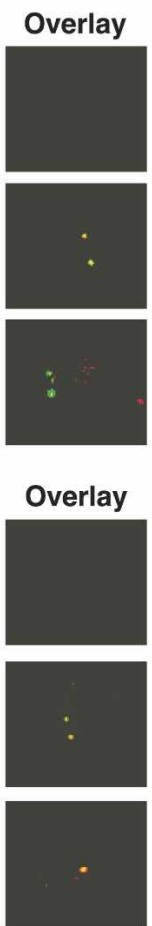

BF

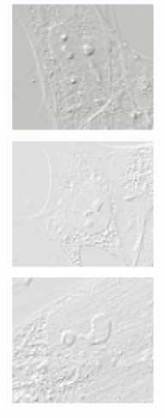

BF

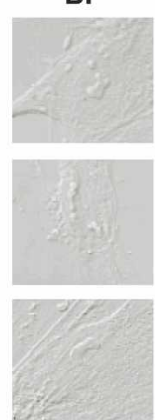

C
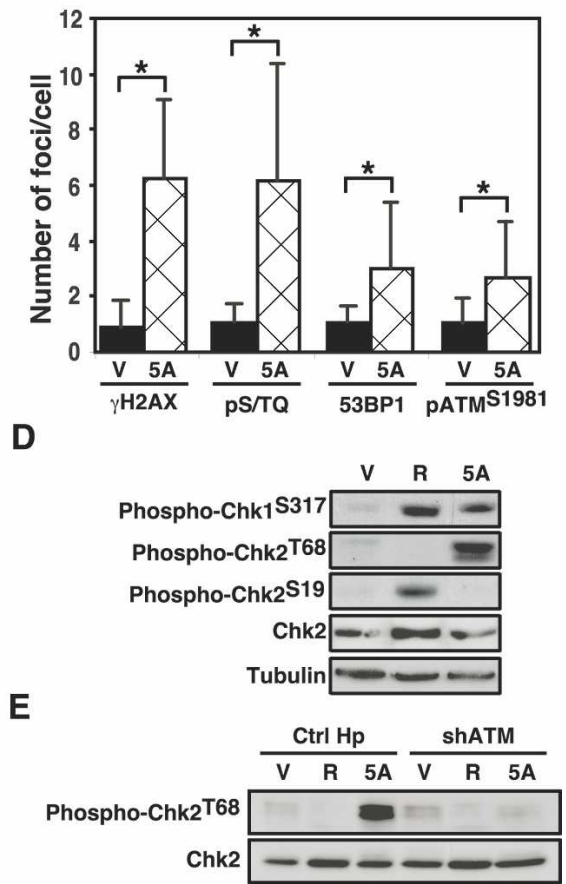

Figure 3. Characterization of the DNA damage signaling pathway in STAT5A-induced senescence. (A) Colocalization 53BP1 foci with phospho-ATM ${ }^{\text {S1981 }}$ in STAT5A1*6-expressing cells by confocal immunofluorescence. $(B)$ Colocalization $\gamma \mathrm{H} 2 \mathrm{AX}$ foci with phospho-S/TQ epitopes in STAT5A1*6-expressing cells by confocal immunofluorescence. $(C)$ Quantitation of DNA damage foci; asterisk represents a $p<0.001$ using the Student's $t$-test. (D) Immunoblots for Chk1 and Chk2 phosphorylation. (V) Vector; (R) RasV12; (5A) STAT5A. (E) ATM is required for phosphorylation of Chk2 at Thr 68 in ca-STAT5A-induced senescence.

2002), or after changes in the chromatin (Bakkenist and Kastan 2003; Hoek and Stillman 2003; Ye et al. 2003). Hence, oncogenes activating dissimilar signaling pathways such as RasV12 or STAT5A may induce DNA damage foci through different mechanisms. We propose to call these foci as ODDI.

\section{ODDI persist in cells that bypassed senescence}

The presence of DNA damage foci characterized both advanced human cancers and premalignant lesions (DiTullio et al. 2002; Bartkova et al. 2005; Gorgoulis et al. 2005). Since those tumors must have already found a way around the senescent barrier, we reasoned that bypassing oncogene-induced senescence might not eliminate ODDI. To investigate this point we used E6 and E7 or E1A to bypass the senescent arrest to both ca-STAT5A and RasV12. As expected, cells expressing E6, E7, and ca-STAT5A, E1A, and ca-STAT5A, E6, E7, and RasV12 or E1A and RasV12 also contained ODDI (Fig. 4). These foci were also labeled by the antibody recognizing phospho-ATM Ser 1981 (Supplementary Fig. 5) and phospho53BP1 (data not shown), suggesting that ATM is active in cells that escape senescence. A quantitation of phosphoATM foci in senescent cells and in cells that bypassed senescence with E1A revealed that the average number of foci did not change (Supplementary Fig. 5). Hence, DNA damage signaling persists after bypassing senescence where it may provide additional anti-proliferative barriers. In fact, it is known that bypassing senescence is not sufficient to transform primary cells (Morales et al.
1999; Dannenberg et al. 2000; Peeper et al. 2001). One possibility is that DNA damage foci activate other barriers to halt cellular transformation.

In conclusion, we propose that oncogenic activity is sensed on the DNA, leading to the formation of ODDI and the activation of the DNA damage signaling pathway. Early in the tumorigenesis process this pathway leads to p53 activation and senescence, but it may also mediate tumor suppression in cells that escape senescence.

\section{Materials and methods}

Cells and retroviruses

IMR90 cells (American Type Culture Collection) and BJ normal fibroblasts (S. Lowe) were cultured in Dulbecco's modified Eagle medium (DMEM, GIBCO) supplemented with $10 \%$ fetal bovine serum (FBS, Hyclone) and $1 \%$ penicillin $\mathrm{G} /$ streptomycin sulfate (GIBCO). pBabe, pBabeRas, pLPC, pLPCE1A, pWZL, and pWZLRas were previously described (Ferbeyre et al. 2000), and LXSN, LXSNE6, LXSNE7, and LXSNE6/E7 were provided by Dr. D. Galloway. STAT5A1 ${ }^{\star} 6$ and STAT5B $1^{\star} 6$ were subcloned from pMXSTAT5A1 ${ }^{\star} 6$ and pMXSTAT5B ${ }^{*} 6$ (Onishi et al. 1998) into pBabe as EcoRI-SalI fragments. shRNA against ATM (shATM) was described by Mukhopadhyay et al. (2005). Retroviralmediated gene transfer, BrdU incorporation, cell cycle analysis, senescence assays, and fluorescence microscopy were done as described (Ferbeyre et al. 2000)

Protein expression analysis

Cells were collected by trypsinization, washed with PBS, lysed in $100 \mu \mathrm{L}$ of SDS sample buffer $(60 \mathrm{mM}$ Tris-HCl at pH 6.8, 10\% glycerol, $2 \%$ SDS, $5 \%$ 2-mercaptoethanol), and boiled for $5 \mathrm{~min}$. Twenty micrograms of total cell protein were separated on SDS-PAGE and transferred to Im- 


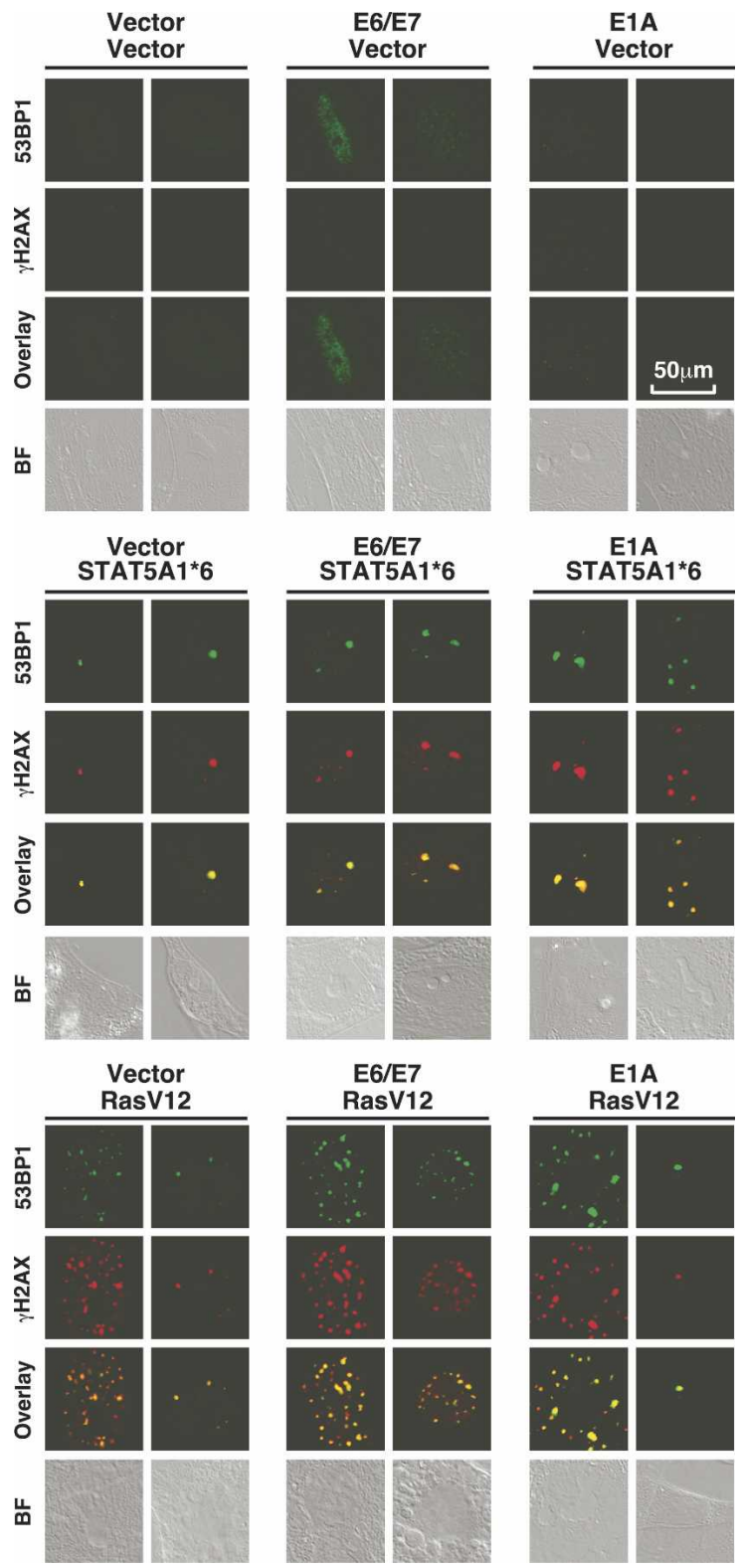

Figure 4. ODDI persist after inactivation of the senescence program. Confocal immunofluorescence of cells stained with anti53BP1 and anti- $\gamma \mathrm{H} 2 \mathrm{AX}$. Two nuclei, representative of the cell population, are shown.

mobilon-P membranes (Millipore). Primary antibodies used were antiphospho-Chk1 ${ }^{\mathrm{S} 317}$ (2344, 1:1000, Cell Signaling), anti-phospho-Chk2 ${ }^{\mathrm{T} 68}$ (2661, 1:1000, Cell Signaling), anti-phospho-Chk2 ${ }^{\text {S19 }}$ (2666, 1:1000, Cell Signaling), anti-Chk2 (2662, 1:1000, Cell Signaling), anti-ATM (from M.B. Kastan, St. Jude Children's Research Hospital, Memphis, TN), and anti- $\alpha$-tubulin (B-5-1-2, 1:5000, Sigma). Signals were revealed after incubation with anti-mouse or anti-rabbit secondary antibodies coupled to peroxidase (Amersham) by using enhanced chemiluminescence (ECL, Amersham) or Lumi-Light ${ }^{\text {PLUS }}$ (Roche). Primary antibodies used for immunofluorescence were anti- $\gamma \mathrm{H} 2 \mathrm{AX}$ (JBW301, 1:200, Upstate Biotechnology), anti-53BP1 (Ab-1, 1:200, Oncogene), anti-pS/TQ epitopes (2851, 1:200, Cell Signaling), anti-phospho-ATM ${ }^{\text {S1981 }}$ (10H11.E12, 1:200, Cell Signaling), anti-TRF2 (4A794, 1:200, Upstate Biotechnology), anti-p53 mix (1801, 1:100, and 421, 1:100, Santa Cruz Biotechnology), and antip53 (CM1, 1:50, Novocastra). Secondary antibodies used were AlexaFluor 488- or AlexaFluor 568-conjugated secondary antibodies (1:1000, Molecular Probes).

\section{Acknowledgments}

We thank E. Querido and members of the Ferbeyre laboratory for comments and technical assistance, and Drs C. Autexier, D. Galloway, T. Kitamura, and S. Lowe for cells and plasmids. This work was supported by CIHR (G.F.) and a fellowship from Fonds de Recherche en Santé du Québec (FRSQ) (F.A.M.).

\section{References}

Bakkenist, C.J. and Kastan, M.B. 2003. DNA damage activates ATM through intermolecular autophosphorylation and dimer dissociation. Nature 421: 499-506.

Bartkova, J., Horejsi, Z., Koed, K., Kramer, A., Tort, F., Zieger, K., Guldberg, P., Sehested, M., Nesland, J.M., Lukas, C., et al. 2005. DNA damage response as a candidate anti-cancer barrier in early human tumorigenesis. Nature 434: 864-870.

Bowman, T., Garcia, R., Turkson, J., and Jove, R. 2000. STATs in oncogenesis. Oncogene 19: 2474-2488.

d'Adda di Fagagna, F., Reaper, P.M., Clay-Farrace, L., Fiegler, H., Carr, P., Von Zglinicki, T., Saretzki, G., Carter, N.P., and Jackson, S.P. 2003. A DNA damage checkpoint response in telomere-initiated senescence. Nature 426: 194-198.

Dannenberg, J.H., van Rossum, A., Schuijff, L., and te Riele, H. 2000 Ablation of the retinoblastoma gene family deregulates $\mathrm{G}(1)$ control causing immortalization and increased cell turnover under growthrestricting conditions. Genes \& Dev. 14: 3051-3064.

de Stanchina, E., McCurrach, M.E., Zindy, F., Shieh, S.Y., Ferbeyre, G., Samuelson, A.V., Prives, C., Roussel, M.F., Sherr, C.J., and Lowe, S.W. 1998. E1A signaling to p53 involves the p19(ARF) tumor suppressor. Genes \& Dev. 12: 2434-2442.

Deng, Q., Liao, R., Wu, B.L., and Sun, P. 2004. High intensity ras signaling induces premature senescence by activating p38 pathway in primary human fibroblasts. J. Biol. Chem. 279: 1050-1059.

Dimri, G.P., Itahana, K., Acosta, M., and Campisi, J. 2000. Regulation of a senescence checkpoint response by the E2F1 transcription factor and p14(ARF) tumor suppressor. Mol. Cell. Biol. 20: 273-285.

DiTullio Jr., R.A., Mochan, T.A., Venere, M., Bartkova, J., Sehested, M., Bartek, J., and Halazonetis, T.D. 2002. 53BP1 functions in an ATMdependent checkpoint pathway that is constitutively activated in human cancer. Nat. Cell Biol. 4: 998-1002.

Ferbeyre, G., de Stanchina, E., Querido, E., Baptiste, N., Prives, C., and Lowe, S.W. 2000. PML is induced by oncogenic ras and promotes premature senescence. Genes \& Dev. 14: 2015-2027.

Ferbeyre, G., de Stanchina, E., Lin, A.W., Querido, E., McCurrach, M.E., Hannon, G.J., and Lowe, S.W. 2002. Oncogenic ras and p53 cooperate to induce cellular senescence. Mol. Cell. Biol. 22: 3497-3508.

Gatei, M., Sloper, K., Sorensen, C., Syljuasen, R., Falck, J., Hobson, K., Savage, K., Lukas, J., Zhou, B.B., Bartek, J., et al. 2003. Ataxia-telangiectasia-mutated (ATM) and NBS1-dependent phosphorylation of Chk1 on Ser-317 in response to ionizing radiation. J. Biol. Chem. 278: 14806-14811.

Gaumont-Leclerc, M.F., Mukhopadhyay, U.K., Goumard, S., and Ferbeyre, G. 2004. PEA-15 is inhibited by adenovirus E1A and plays a role in ERK nuclear export and Ras-induced senescence. J. Biol. Chem. 279: 46802-46809.

Gorgoulis, V.G., Vassiliou, L.V., Karakaidos, P., Zacharatos, P., Kotsinas, A., Liloglou, T., Venere, M., Ditullio Jr., R.A., Kastrinakis, N.G., Levy, B., et al. 2005. Activation of the DNA damage checkpoint and genomic instability in human precancerous lesions. Nature 434: 907 913.

Hoek, M. and Stillman, B. 2003. Chromatin assembly factor 1 is essential and couples chromatin assembly to DNA replication in vivo. Proc. Nat1. Acad. Sci. 100: 12183-12188.

Lee, A.C., Fenster, B.E., Ito, H., Takeda, K., Bae, N.S., Hirai, T., Yu, Z.X., Ferrans, V.J., Howard, B.H., and Finkel, T. 1999. Ras proteins induce senescence by altering the intracellular levels of reactive oxygen species. J. Biol. Chem. 274: 7936-7940.

Lin, A.W. and Lowe, S.W. 2001. Oncogenic ras activates the ARF-p53 pathway to suppress epithelial cell transformation. Proc. Natl. Acad. Sci. 98: 5025-5030.

Lowe, S.W., Cepero, E., and Evan, G. 2004. Intrinsic tumour suppression. Nature 432: 307-315. 


\section{Mallette et al.}

Mallette, F.A., Goumard, S., Gaumont-Leclerc, M.F., Moiseeva, O., and Ferbeyre, G. 2004. Human fibroblasts require the Rb family of tumor suppressors, but not p53, for PML-induced senescence. Oncogene 23: 91-99.

Matsuoka, S., Rotman, G., Ogawa, A., Shiloh, Y., Tamai, K., and Elledge, S.J. 2000. Ataxia telangiectasia-mutated phosphorylates Chk2 in vivo and in vitro. Proc. Nat1. Acad. Sci. 97: 10389-10394.

Moiseeva, O., Mallette, F.A., Mukhopadhyay, U.K., Moores, A., and Ferbeyre, G. 2006. DNA damage signaling and p53-dependent senescence after prolonged $\beta$-interferon stimulation. Mol. Biol. Cell 17: 1583-1592.

Morales, C.P., Holt, S.E., Ouellette, M., Kaur, K.J., Yan, Y., Wilson, K.S., White, M.A., Wright, W.E., and Shay, J.W. 1999. Absence of cancerassociated changes in human fibroblasts immortalized with telomerase. Nat. Genet. 21: 115-118.

Mukhopadhyay, U.K., Senderowicz, A.M., and Ferbeyre, G. 2005. RNA silencing of checkpoint regulators sensitizes p53-defective prostate cancer cells to chemotherapy while sparing normal cells. Cancer Res. 65: 2872-2881.

Onishi, M., Nosaka, T., Misawa, K., Mui, A.L., Gorman, D., McMahon M., Miyajima, A., and Kitamura, T. 1998. Identification and characterization of a constitutively active STAT5 mutant that promotes cell proliferation. Mol. Cell. Biol. 18: 3871-3879.

Osborn, A.J., Elledge, S.J., and Zou, L. 2002. Checking on the fork: The DNA-replication stress-response pathway. Trends Cell Biol. 12: 509_ 516.

Palmero, I., Pantoja, C., and Serrano, M. 1998. p19ARF links the tumour suppressor p53 to Ras. Nature 395: 125-126.

Pearson, M., Carbone, R., Sebastiani, C., Cioce, M., Fagioli, M., Saito, S., Higashimoto, Y., Appella, E., Minucci, S., Pandolfi, P.P., et al. 2000. PML regulates p53 acetylation and premature senescence induced by oncogenic Ras. Nature 406: 207-210.

Peeper, D.S., Dannenberg, J.H., Douma, S., te Riele, H., and Bernards, R. 2001. Escape from premature senescence is not sufficient for oncogenic transformation by Ras. Nat. Cell Biol. 3: 198-203.

Rouse, J. and Jackson, S.P. 2002. Interfaces between the detection, signaling, and repair of DNA damage. Science 297: 547-551.

Serrano, M., Lin, A.W., McCurrach, M.E., Beach, D., and Lowe, S.W 1997. Oncogenic ras provokes premature cell senescence associated with accumulation of p53 and p16INK4a. Cell 88: 593-602.

Shimuta, K., Nakajo, N., Uto, K., Hayano, Y., Okazaki, K., and Sagata, N 2002. Chk1 is activated transiently and targets Cdc25A for degradation at the Xenopus midblastula transition. EMBO I. 21: 3694-3703.

Tolbert, D., Lu, X., Yin, C., Tantama, M., and Van Dyke, T. 2002. p19(ARF) is dispensable for oncogenic stress-induced p53-mediated apoptosis and tumor suppression in vivo. Mol. Cell. Biol. 22: 370 377.

Vafa, O., Wade, M., Kern, S., Beeche, M., Pandita, T.K., Hampton, G.M. and Wahl, G.M. 2002. c-Myc can induce DNA damage, increase re active oxygen species, and mitigate p53 function: A mechanism for oncogene-induced genetic instability. Mol. Cell 9: 1031-1044.

Wang, B., Matsuoka, S., Carpenter, P.B., and Elledge, S.J. 2002. 53BP1, a mediator of the DNA damage checkpoint. Science 298: 1435-1438.

Wei, S., Wei, S., and Sedivy, J.M. 1999. Expression of catalytically active telomerase does not prevent premature senescence caused by overexpression of oncogenic Ha-Ras in normal human fibroblasts. Cance Res. 59: 1539-1543.

Wei, W., Hemmer, R.M., and Sedivy, J.M. 2001. Role of p14(ARF) in replicative and induced senescence of human fibroblasts. Mol. Cell. Biol. 21: 6748-6757.

Wu, C., Miloslavskaya, I., Demontis, S., Maestro, R., and Galaktionov, K. 2004. Regulation of cellular response to oncogenic and oxidative stress by Seladin-1. Nature 432: 640-645.

Xu, X., Tsvetkov, L.M., and Stern, D.F. 2002. Chk2 activation and phosphorylation-dependent oligomerization. Mol. Cell. Biol. 22 4419-4432.

Ye, X., Franco, A.A., Santos, H., Nelson, D.M., Kaufman, P.D., and Adams, P.D. 2003. Defective S phase chromatin assembly causes DNA damage, activation of the $\mathrm{S}$ phase checkpoint, and S phase arrest. Mol. Cell 11: 341-351.

Zhao, H. and Piwnica-Worms, H. 2001. ATR-mediated checkpoint pathways regulate phosphorylation and activation of human Chk1. Mol. Cell. Biol. 21: 4129-4139.
Zindy, F., Eischen, C.M., Randle, D.H., Kamijo, T., Cleveland, J.L., Sherr C.J., and Roussel, M.F. 1998. Myc signaling via the ARF tumor suppressor regulates p53-dependent apoptosis and immortalization. Genes \& Dev. 12: 2424-2433.

Zindy, F., Williams, R.T., Baudino, T.A., Rehg, J.E., Skapek, S.X., Cleveland, J.L., Roussel, M.F., and Sherr, C.J. 2003. Arf tumor suppressor promoter monitors latent oncogenic signals in vivo. Proc. Natl. Acad. Sci. 100: 15930-15935. 


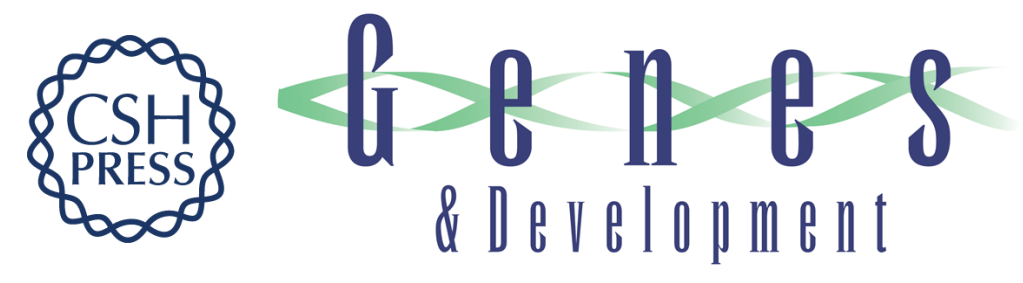

\section{The DNA damage signaling pathway is a critical mediator of oncogene-induced senescence}

Frédérick A. Mallette, Marie-France Gaumont-Leclerc and Gerardo Ferbeyre

Genes Dev. 2007, 21:

Access the most recent version at doi:10.1101/gad.1487307

\section{Supplemental http://genesdev.cshlp.org/content/suppl/2007/01/18/21.1.43.DC1 \\ Material}

Related Content

Oncogenes and senescence: breaking down in the fast lane

Michael T. Hemann and Masashi Narita

Genes Dev. January , 2007 21: 1-5

References This article cites 42 articles, 25 of which can be accessed free at:

http://genesdev.cshlp.org/content/21/1/43.full.html\#ref-list-1

Articles cited in:

http://genesdev.cshlp.org/content/21/1/43.full.html\#related-urls

License

Email Alerting Receive free email alerts when new articles cite this article - sign up in the box at the top Service right corner of the article or click here.

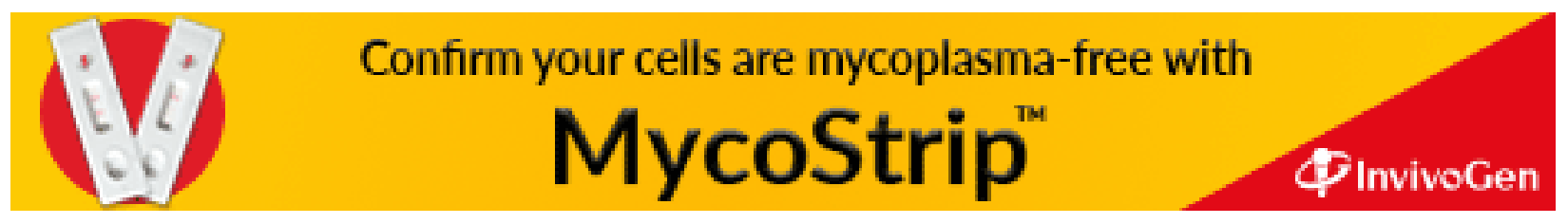

